\title{
Maize Market Integration: A Case Study of Maize Marketing In Ghana
}

\author{
Francis Srofenyoh \\ Central Business School, Central University College, Ghana \\ Email:francissrofenyob@gmail.com
}

\begin{abstract}
Agricultural marketing remains a challenge; this is because a large proportion of the population is engaged in a form of small-scale agricultural production and marketing that is characterised by a multitude of constraints and market imperfections. Paramount among the constraints are limited land availability, poor physical and legal infrastructure, high transaction costs and few available and alternative livelihood support systems. For some of these constraints to be removed, there is the need for information flow. Thus, it is believed that, spatial price transmission or market integration measures, the degree to which markets at geographically separated locations share common long-run price or trade information on a homogenous commodity. Using the co-integration approach, the results of the study using either Techiman or Kumasi as the producer markets of maize, the following markets Bolga, Wa, Ho, Tamale, Mankesim, Koforidua, Accra, Cape Coast and Takoradi/Sekond (as consumer markets) shows that there is a long run price transmission relations with the consumer markets. However, Bolgatanga market is the only exception. It is recommended that the Ministry of Food and Agriculture should intensify collection and dissemination of data on maize prices to both consuming markets and producing markets. This can be enhanced by Government establishing market information centres in these markets where both traders and farmers could go for information on the price trend of the commodity in other market(s).
\end{abstract}

Keywords: Co-integration; Marketing; Market Integration; Non-stationarity; stochastic process.

\section{Introduction}

Although considerable changes have occurred in the macroeconomic policy framework within which the agricultural sector operates, agricultural marketing remains a challenge to the sector; this is because a large proportion of the population is engaged in small-scale farming and marketing that is characterised by a multitude of constraints and market imperfections. Paramount among the constraints are limited land availability, poor physical and legal infrastructure, high transactions costs and few available and alternative livelihood support systems. Evolution of effective tools to improve the welfare of farmers and promote economic development in Ghana with large populations in agriculture, should involve some analysis of properties of agricultural commodity markets and their impact. Thus, a study of the dynamics of markets integration including efficiency should inform policy makers on how long an initial localized scarcity could be expected to persist, given that the necessary transport infrastructure exists.

One of the factors that determine the efficiency of a marketing system is the type of market structure that prevails (Dittoh, 1994). Marketing efficiency is more likely to be high in a competitive market than in a less competitive one (ibid). Researchers are divided on the issues of market efficiency and market competitiveness. Some researchers have claimed that the existence of many intermediaries in the marketing chain results in marketing inefficiencies (Adegeye and Dittoh, 1986), but others have argued that it ensures efficient use of available resources (Wilcock, 1978). While Miracle (1968) argued that prices are competitive and therefore low at the farm gate and rural retail markets but are uncompetitive and thus high after the produce leaves local assembly market, Anthonio (1973) was of the view that the issue of competitiveness is not a major determinant of high urban prices. Rather, the major cause is high marketing costs resulting largely from poor storage, high transport costs, and high degree of risks.

However a few empirical investigations (Alderman, 1992; Bediane and Shively, 1997; Abdulai, 2000) have examined the performance of agricultural markets for maize, sorghum and rice following trade liberalisation in Ghana. The results of these studies indicates that grain markets in Ghana are fairly integrated. A study by Amikuzuno (2009) on integration of tomato markets in Ghana also shows that market integration in Ghanaian tomato trade is mainly ensured by error correction on the two main producer markets, Navrongo and Techiman, while the 
consumer markets for the most part do not error correct. Amikuzuno (2009) were of the view that overall, the integration of Ghanaian tomato markets seems to be rather strong, with the correction of disequilibria taking only a few weeks. A related study by Dittoh, (1994) indicates that there is little and a low degree of integration of pepper and tomato in Nigeria, however, some market integration exist between major producing and major consuming areas. The results also indicate that good access roads are important for markets to be integrated, but the distance between markets is not an issue. The study concludes that the cobweb problem seems to be present and micro-level social, political and economic factors significantly affect vegetable marketing decisions. Thus the present study attempts to answer the following question; what are the production and consumption patterns of maize; what are the challenges of maize marketing in Ghana, and what is the nature of the maize market in Ghana.

Therefore, this paper attempts to analyse the production, consumption patterns of maize and the challenges of maize marketing in Ghana and price transmission patterns of maize. The import of this lies in the fact that in an integrated commodity market, there will be less covariance between individual outputs and the aggregate supply, thus implying less risk and higher incomes (Dittoh, 1994).

The rest of the paper is divided into three sections. The second section looks at method of assessing market integration. The third section reviews maize marketing systems in Ghana and its associated constraints and presents the results of the co integration analysis. The final section, section four, presents conclusions and recommendations.

\section{Methodology}

\subsection{The concept of Market Integration and Price Transmission}

Spatial price transmission or market integration measures the degree to which markets at geographically separated locations share common longrun price or trade information on a homogenous commodity (Amikuzuno, 2009). The concept of market integration according to FAO (2003), given prices for a commodity in two spatially separated markets $p_{1 t}$ and $p_{2 t}$, the Law of One Price and the Enke-Samuelson-Takayama-Judge model, postulate that at all points of time, allowing for transfer costs $c$, for transporting the commodity from market 1 to market 2, the relationship between the prices is as follows:

$$
p_{1 t}=p_{2 t}+c
$$

If a relationship between two prices, such as (1), holds, the markets can be said to be integrated.

\subsection{Stationarity Test}

The literature on market integration has shown that previous studies which have not explored the time series properties, non-stationarity, of the variables were in-appropriate (Adreni, 1989). For example, Jones (1968, 1972), Gilbert (1969), Thodey (1969), and other researchers have used the bivariate correlation coefficient to measure market integration and to infer marketing efficiency. It has been criticized that the use of this measure shows inappropriateness in measuring market efficiency (Blyn, 1973; Hariss, 1979; Eicher and Baker, 1982). This is based on the assumption that the primary commodity prices obey a perfect arbitrage rule. Thus, application of the non-stationarity applications to invalidates procedures and make classical assumptions asymptotic theory inapplicable. A stochastic process is said to be stationary if the joint and conditional probability distributions of the process are unchanged if displaced in time (Charemza and Deadman, 1993). In order words, if the mean, variance and the covariance of the variables in question are constant over time (ibid). The value of the covariance between two periods depends only on the gap between the periods, and not the actual time, at which the covariance is considered. If one or more of the conditions above are not fulfilled, the process is said to be non-stationary. A non-stationary series which can be transformed to a stationary series by differencing, $d$ times is said to be integrated of order, $d$.

Consider a time series $y$ and its autoregressive representation:

$$
\mathrm{y}_{\mathrm{t}}=\varrho_{\mathrm{t}-1}+\varepsilon_{\mathrm{t}} \text {, where } \mathrm{y}_{0}=0
$$

The above series y is said to be stationary if $/ \varrho /<$ 1. This means that roots of the associated difference equation lie outside the unit circle. If $/ \varrho /=1$, the series is said to be non-stationary, it has a unit root and a variance of $y_{t}$ is $t \sigma^{2}$. To test for the stationarity characteristics of the data, the order of integration (unit root), the Dicky-Fuller $(\mathrm{DF})^{1}$, and Augmented Dickey-Fuller (ADF) tests are estimated using E-views. A summary result of the unit root test results are presented in Table 4. As shown in the Table 4, the result suggests that all the series used in the analysis does have a unit root except Bolgatanga maize price. 
In order words the series are not stationary and thus cannot be used for a regression analysis whose results can be trusted. When the series were subjected to a further test, it was realized that all the series have a unit root of 1 except Bolgatanga price series. In order words the price series are integrated with order one (Table 4).

The above test clearly indicates that any regression analysis with the above series would result in dubious coefficients. It is important to note that according to Charemza and Deadman (1993) the definition and indeed the entire problem of enquiry into stationarity become more complex in the case where the series is subject to seasonality (for example monthly price data as in this case). As a result of the above problem, the study is limited to estimating market integration using co-integration approach. The cointegration approach has become the obvious choice of determining market integration, since there is a unit root in all the series under consideration. Its application is acceptable if there is a unit root in series. With the existence of a unit root, it is postulated that the series might have along run relation.

\subsection{Market Integration Using Co-Integration Approach}

Now applying the above notion to the maize markets in Ghana, assume that $P_{m t}$ is the price of maize in Techiman market and $P_{m a}$ is the price of maize in Accra market. Then we can write.

$$
P_{m t} \quad=\quad \varphi\left(P_{m a}\right)^{\beta}
$$

The above equation can be expressed in logarithm form as follows.

$$
\ln P_{m t}=\varphi+\beta \operatorname{In} P_{m a}+\varepsilon_{\mathrm{t}},
$$

Where $\varphi$ is a constant.

Given that the above equations holds and fulfils all the necessary assumptions of OLS, then $\varepsilon_{t}$ represents the deviations from the equilibrium value at each time $t$. Thus, if $\varepsilon_{t} \sim(0)$, then $P_{m t}$ and $P_{m a}$ are said to be conintegrated and the two market are thus integrated. In order words there is causality between the two markets in the sense of Granger (1988). The above models is used to analyse the dynamics of maize market price transmission in Ghana.
The data used for this study consists of monthly wholesale maize prices for selected markets collected by the Ministry of Food and Agriculture between 2000 and 2010. Techiman and Kumasi Markets are chosen as the producer market for maize in the country as against the following consumer markets for maize (Bolga, Wa, Ho, Tamale, Mankesim, Koforidua, Accra, Cape coast and Takoradi/Sekondi). Techiman and Kumasi markets were chosen because the bulk of maize marketing in Ghana takes place in these two markets and the two markets are very close to major maize producing areas (Nkoranza in the Brong Ahafo Region and Ejura in the Ashanti Region).

\section{Results and Discussion}

\subsection{Maize Production and Consumption}

Maize is chosen for this because it is one of the most important staple cereal food crops in Ghana and its production occupies about $27 \%$ of all land under major food crops and about 51.6 percent of land under all cereals (Seini, 2002). The importance of maize cannot be over-emphasised. The crop is grown in all agro-ecological zones of the country. However, the transitional and the northern guinea savannah regions of Ghana account for about 70 percent of maize output (Ibid). The number of households involved in maize production in Brong Ahafo and Ashanti Regions is estimated at $600,000-1,000,000$ (SRID, 2010). Nationally, maize and cassava are second to cocoa in land use (793,000 ha, 790,000 ha, and 1,835,000 respectively), making maize a significant crop in Ghana. An important characteristic of the production of the crop is that, over 90 percent of maize production is in the hands of smallholders who produce maize in scattered farm plots ranging from less than half a hectare to about 3 hectares (Ibid). Maize is grown almost everywhere in Ghana. However, the main areas accounting for more than $60 \%$ of the $1,188,836$ metric tonnes of maize produced in 2009 are the Brong Ahafo, parts of Ashanti and the Eastern Regions (Kwadzo and Srofenyoh, 2012). An estimated $15 \%$ is grown in the three northern regions of the country. On average, the quantity of maize produced in Ghana has increased annually by $3.1 \%$ (2000 - 2009) (Ibid).

\subsection{Dataset}


Table 1

Maize Production and Real Wholesale Price of Maize in Ghana (2000-2009)

\begin{tabular}{lcc}
\hline Year & Real Wholesale Price of Maize (per MT) & 000'MT \\
\hline 2000 & 136.04 & 1013 \\
2001 & 158.78 & 1400 \\
2002 & 134.13 & 1289 \\
2003 & 119.25 & 1158 \\
2004 & 141.99 & 1171 \\
2005 & 192.59 & 1189 \\
2006 & 122.81 & 1220 \\
2007 & 129.32 & 1470 \\
2008 & 206.63 & 1620 \\
\hline
\end{tabular}

Source: Conputed by author

Table 1 above show maize production in Ghana between 2000 and 2009. Since maize is an important crop, increases in its production, like other important food crops featured prominently in almost all policies pursued by the government.

Table 2

Estimation of consumption of white maize produced in Ghana (2008)

\begin{tabular}{lcc}
\hline Consumption category & MT & \% of Total Consumption \\
\hline$\%$ of Total Consumption & 675,000 & 57 \\
Poultry and fish feed & 150,000 & 13 \\
Formally traded for human consumption & 170,000 & 16 \\
Informally traded for human consumption & 184,000 & 100 \\
Total production & $1,188,000$ & \\
\hline
\end{tabular}

Source: Conputed by author 


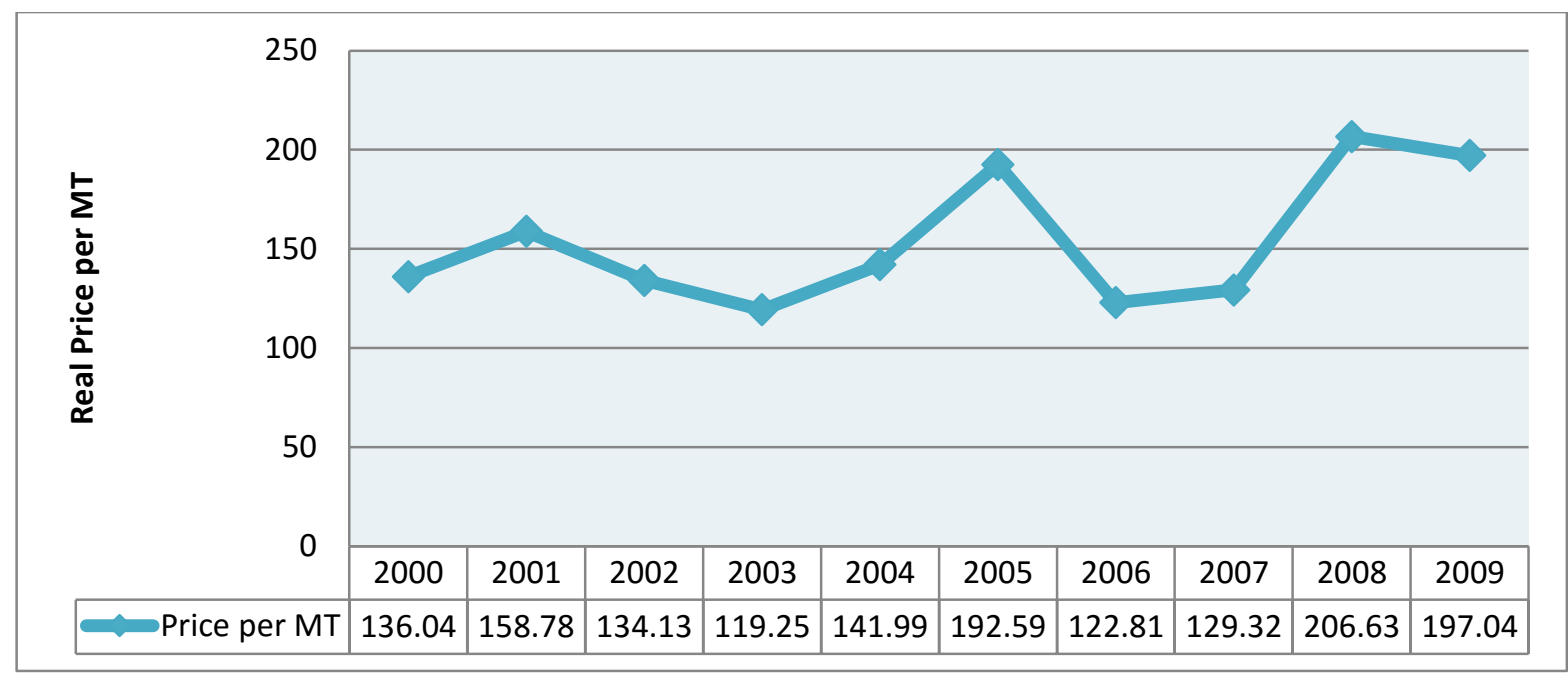

Fig. 1: Real Wholesale Price of Maize (2000 - 2009)

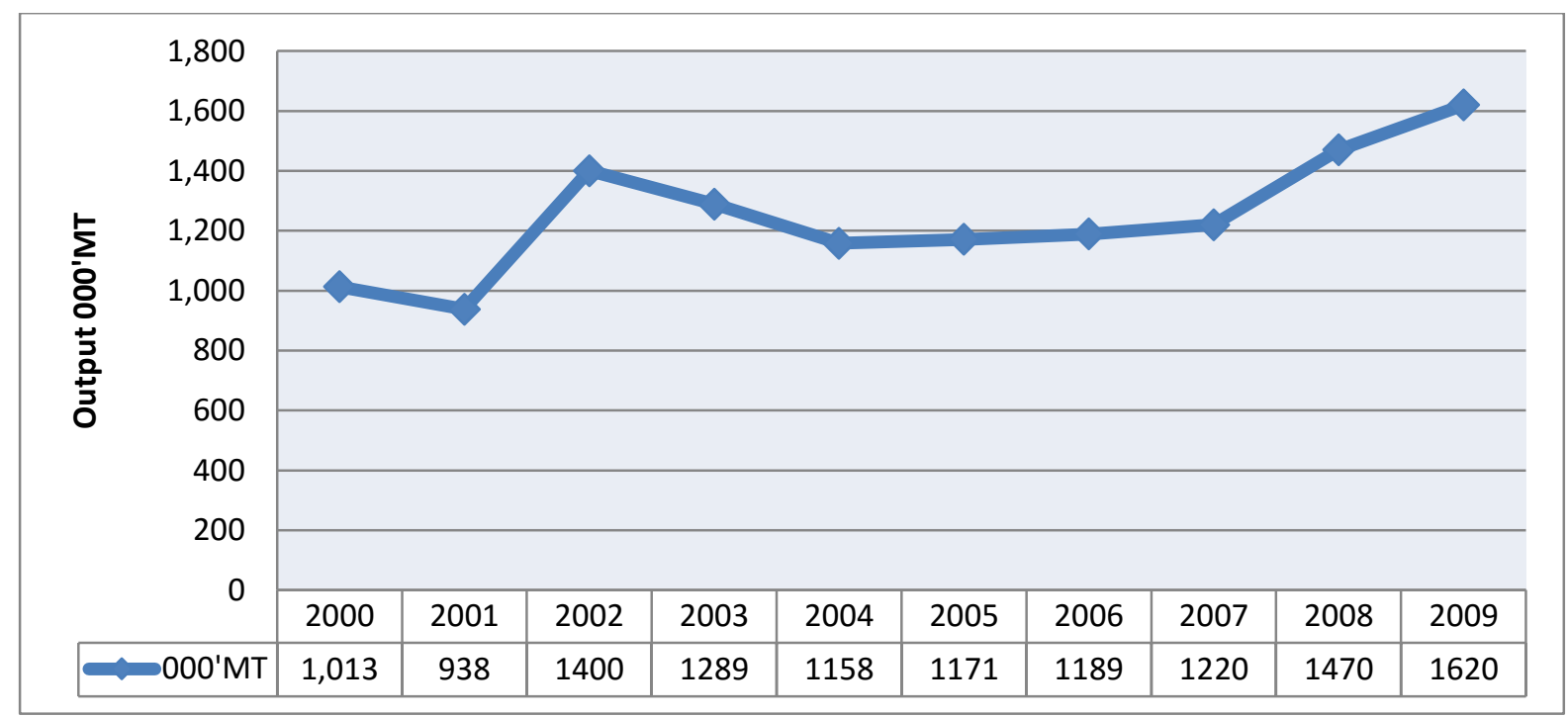

Fig. 2: Output of maize (2000-2009)

Tables 1 and 2 and Figures 1 and 2 provide data on maize production, the wholesale price and real wholesale price. As shown in figure 1, real wholesale price of maize was highest in 2008. Many factors could account for this cyclical movement of the real wholesale price of maize. For example any year that there is a bumper harvest prices decline, which serves as a dis-incentive and farmers consequently decrease their investment in production. In addition, the above situation worsens since there are inadequate and proper storage facilities in the country for storing the crop for a long period. The result is that what is produced in a particular year has to be released onto the market. Another possible factor that could explain the trend is that most maize farmers are small scale holders and poor, thus their income is very low. As such when they harvest the crop they are forced to sell for paying school fees and for buying other food stuffs $^{2}$. The overall effect of all these is that output price of the crop becomes very volatile to the disadvantage of farmers. Table 2 above provides information on domestic consumption of maize in Ghana. The main consumption of maize is at the household level $(73 \%)$. Of the household consumed maize, only about $16 \%$ is traded and the rest $57 \%$ consumed by those who produced them. This imply that maize remain a subsistent crop (Kwadzo and Srofenyoh, 2012). The importance of cereal for that 
maize has necessitated the government to evolved strategies to operationalised buffer stock of $15,000 \mathrm{mt}$ of domestically produced maize and rice (Nyanteng and Asuming-Bempong, 2003). The objectives of this strategy is to:

- Put to use some modern storage facilities located in strategic places in the country belonging to the almost defunct Ghana Food Distribution Corporation (GFDC)

- Reduce the high post-harvest food losses

- Reduce the extent that producer prices collapse in the immediate post-harvest periods

- Reduce the high consumer food prices in the periods before the next harvests

\subsection{Constraints of Maize Marketing}

There are institutional arrangements for marketing of traditional export crops, namely, cocoa, coffee and sheanuts. In addition, marketing of tobacco and cotton is well organised because these crops are produced to feed local manufacturing companies. The case of maize is different, there are no standards. A study by Asante (undated) reveals that sacks used to purchase maize by traders can vary by as much $20 \%$ and moisture content is not properly determined hence traders must depend on their experience to determine moisture content. According to Asante (undated) participants in the maize market consist of producers and marketing intermediaries from both the state and private sectors. The private sector is competitive (with many smallscale traders) and handles over $90 \%$ of the grain market.

Table 3

Marketing channels for farmers

\begin{tabular}{lcc}
\hline Sales channels & Frequency & $\begin{array}{c}\text { Percenta } \\
\text { ge }\end{array}$ \\
\hline GFDC & 98 & 29.5 \\
\hline
\end{tabular}

\begin{tabular}{lcc}
\hline Ghana Seed Company & 6 & 1.8 \\
$\begin{array}{l}\text { Grains Warehouse } \\
\text { Company }\end{array}$ & 4 & 4.2 \\
Commercial store/firm & 8 & 5.4 \\
Private traders & 312 & 94.0 \\
Factory/cannery/mills & 17 & 5.1 \\
Institutions (eg. schools) & 89 & 26.8 \\
Others & 23 & 6.9 \\
Number of farmers & 332 & \\
\hline
\end{tabular}

Table 3 provides the sales channels of maize in Ghana. Asante (undated) has identified five main participants in the maize trade as follows; the farmer/seller, the local assembler, the commission agent, the longdistance wholesaler, the market-based wholesaler and the market-based retailer. It was indicated that the long-distance wholesalers and their local assemblers are the major agents in the trade, and buy over $70 \%$ of marketed maize (Armah, 1989). A study by Kwadzo and Srofenyoh (2012) reveals that the major constraints confronting the maize traders in Ghana are customers who buy on credit do not pay on schedule and increases in transport fares due mainly to fuel price increases. They were of the view that most of wholesale market trader's working capital is in debt, lack of proper maize storage facilities in the market place and traders are facing declining demand for maize. This is largely because maize meals demand more intervening processing; people are shifting to rice consumption due to convenience and number of people entering the maize trade is increasing.

\subsection{Maize Market Integration}

The test result is as shown in table 4 and 5 using Techiman as the producer market. 


\section{Table 4}

Results of the Unit Root Test

\begin{tabular}{|c|c|c|c|c|}
\hline \multirow[t]{2}{*}{$\begin{array}{l}\text { Natural Logarithm } \\
\text { Price Series }\end{array}$} & \multicolumn{2}{|c|}{$\begin{array}{l}\text { With Constant and Trend } \\
\text { (No differencing) }\end{array}$} & \multicolumn{2}{|c|}{$\begin{array}{l}\text { With Constant and Trend but differenced one } \\
\text { and lagged period }\end{array}$} \\
\hline & $\begin{array}{l}\text { ADF Computed } \\
\text { Test Statistic }\end{array}$ & $\begin{array}{l}\text { MacKinnon critical } \\
\text { values for rejection of } \\
\text { hypothesis of a unit } \\
\text { root }(5 \%)\end{array}$ & $\begin{array}{l}\text { ADF Computed } \\
\text { Test Statistic }\end{array}$ & $\begin{array}{c}\text { MacKinnon critical } \\
\text { values for rejection of } \\
\text { hypothesis of a unit root } \\
(5 \%)\end{array}$ \\
\hline Maize Price_Accra & -0.879145 & -3.5066 & -4.148540 & -3.5112 \\
\hline $\begin{array}{l}\text { Maize Price_ } \\
\text { Bolgatanga }\end{array}$ & -3.788912 & -3.5066 & -6.361139 & -3.5112 \\
\hline $\begin{array}{l}\text { Maize Price_Cape } \\
\text { Coast }\end{array}$ & -2.661212 & -3.5066 & -6.001894 & -3.5112 \\
\hline Maize Price_Ho & -1.636329 & -3.5088 & -5.681381 & -3.5136 \\
\hline $\begin{array}{l}\text { Maize Price_ } \\
\text { Koforidua }\end{array}$ & -1.640887 & -3.5066 & -4.909966 & -3.5112 \\
\hline Maize Price_Kumasi & -1.897486 & -3.5066 & -4.362951 & -3.5112 \\
\hline $\begin{array}{l}\text { Maize Price_ } \\
\text { Mankesim }\end{array}$ & -2.436221 & -3.5088 & -4.495570 & -3.5136 \\
\hline Maize Price_Sunyani & -1.909155 & -3.5066 & -5.267513 & -3.5112 \\
\hline Maize Price_Tamale & -0.865954 & -3.5066 & -4.234122 & -3.5112 \\
\hline $\begin{array}{l}\text { Maize Price_ } \\
\text { Techiman }\end{array}$ & -1.836320 & -3.5066 & -5.644159 & -3.5112 \\
\hline Maize Price_Wa & -0.956381 & -3.5066 & -4.061933 & -3.5112 \\
\hline $\begin{array}{l}\text { Maize Price_ } \\
\text { Sekondi/ Takoradi }\end{array}$ & -1.842281 & -3.5066 & -6.070156 & -3.5112 \\
\hline
\end{tabular}


Table 5

Results of the Unit Root Test for the Residuals - Techiman

\begin{tabular}{|c|c|c|}
\hline \multirow[t]{2}{*}{ Residuals } & \multicolumn{2}{|c|}{ With Constant and Trend } \\
\hline & $\begin{array}{l}\text { ADF Computed Test } \\
\text { Statistic }\end{array}$ & $\begin{array}{c}\text { MacKinnon critical values for rejection } \\
\text { of hypothesis of a unit root }\end{array}$ \\
\hline Residuals Techiman_Accra & -3.946941 & $-3.5066(5 \%)$ \\
\hline Residuals Techiman_Bolgatanga & -2.830858 & $\begin{array}{c}\text { Not significant at the } 1 \%, 5 \% \text { \& } 10 \% \\
\text { significance levels }\end{array}$ \\
\hline Residuals Techiman_Cape Coast & -3.263868 & $-3.1828(10 \%)$ \\
\hline Residuals Techiman_Ho & -3.415322 & $-3.1840(10 \%)$ \\
\hline Residuals Techiman_Koforidua & -4.090072 & $-3.5066(5 \%)$ \\
\hline Residuals Techiman_Kumasi & -4.098549 & $-3.5066(5 \%)$ \\
\hline Residuals Techiman_Mankesim & -3.344847 & $-3.1840 \quad(10 \%)$ \\
\hline Residuals Techiman_Sunyani & -3.378247 & $-3.1828(10 \%)$ \\
\hline Residuals Techiman_Tamale & -4.679265 & $-4.1630(1 \%)$ \\
\hline Residuals Techiman_Wa & -3.476876 & $-3.1828 \quad(10 \%)$ \\
\hline Residuals Techiman_Sekondi/ Takoradi & -3.440160 & $-3.1828(10 \%)$ \\
\hline
\end{tabular}

The results show that the consumer market under consideration does have a weak long run price transmission relation with the producer market. Bolgatanga however, is an exception. The analysis shows that there is no price transmission signal between Bolgatanga market and Techiman. An interesting discovery was that the Tamale market was the only market with very strong long term price transmission relationship with Techiman market as shown by the significance of the unit root test on the residual at $1 \%$. The second best were Accra, Koforidua and Kumasi. Using Kumasi as the producer market as shown below, the result is slightly different. 
Table 6

Results of the Unit Root Test for the Residuals - Kumasi

\begin{tabular}{|c|c|c|}
\hline \multirow[t]{2}{*}{ Residuals } & \multicolumn{2}{|c|}{ With Constant and Trend } \\
\hline & ADF Computed Test Statistic & $\begin{array}{c}\text { MacKinnon critical values for rejection } \\
\text { of hypothesis of a unit root }(5 \%)\end{array}$ \\
\hline Residuals Kumasi_Accra & -4.239084 & $-4.1630(1 \%)$ \\
\hline Residuals Kumasi__Bolgatanga & -3.285505 & $-3.1828(10 \%)$ \\
\hline Residuals Kumasi_Cape Coast & -4.229074 & $-4.1630(1 \%)$ \\
\hline Residuals Kumasi_Ho & -4.523935 & $-4.1678(1 \%)$ \\
\hline Residuals Kumasi_Koforidua & -5.366569 & $-4.1630(1 \%)$ \\
\hline Residuals Kumasi_Techiman & -4.821408 & $-4.1630(1 \%)$ \\
\hline Residuals Kumasi_ Mankesim & -4.874952 & $-4.1678(1 \%)$ \\
\hline Residuals Kumasi_Sunyani & -4.925896 & $-4.1630(1 \%)$ \\
\hline Residuals Kumasi_Tamale & -4.815002 & $-4.1630 \quad(1 \%)$ \\
\hline Residuals Kumasi_Wa & -3.780142 & $-3.5066(5 \%)$ \\
\hline Residuals Kumasi_Sekondi/ Takoradi & -5.477369 & $-4.1630(1 \%)$ \\
\hline
\end{tabular}

With the exception of Bolgatanga market which had relatively weak long run price transmission signals with Kumasi market, the rest of the consumer markets had very strong long run price transmission signals with Kumasi market. The unit root tests on the residuals for the consumer markets with Kumasi were significant at the $1 \%$ significance level. The findings here agree with findings by Mabaya (2002) in Zimbabwean tomato markets and Abdulai (2000) and Alderman (1992) in Ghanaian grain markets.

In fact the ESSOKO has started collecting and disseminating market price information. The organisation is collecting data on commodity prices from major markets in Ghana, which is made available to market women. The price data is accessed using mobile phones. The challenge of this approach could be getting farmers involved. However, Jensen (2007) sheds light on the importance of information flow on price behaviour in spatially separated markets. Fackler and Tastan (2008) as well as Stephens et al. (2008) also find evidence that information flow across markets and trader networks might lead to the transmission of price signals between markets without trade flows. Hence, mechanisms other than direct trade, such as information exchange among suppliers, might lead to price adjustment in periods during which no trade takes place. Another possibility is that producers located in space between two or more markets determine where to deliver their produce after examining the relative prices in the neighbouring markets. Thus, markets also be integrated by producer decisions even though no direct trade takes place between them.

\section{Conclusions}

The study uses co-integration approach to analyse long run relationship between major maize producer markets in Ghana (Techiman and Kumasi market) and consumer markets. The study results show that there is a long run price transmission signals between the major maize producer and the consumer markets in Ghana as shown by the presence of a unit root in the residuals of the regression analysis.

\subsection{Recommendations}

The following recommendations are made on the basis of the findings:

- If Ghanaian farmers and traders should benefit from the strong long run price 
transmission relationship between the major maize markets in Ghana, then Ministry of Food and Agriculture should intensify collection and dissemination of data on maize prices to both consuming markets and producing markets. The improved communication or dissemination of future maize prices may therefore offer significant potential benefits to the private sector's decision on maize marketing and storage. In addition, Government could establish market information centres in these markets where both traders and farmers could access information on the price trend of the commodity in other markets in the country. With this information, it is expected that farmers would re-allocate their scarce resources and be able to increase production should the need arises. Traders can also move the commodity to other markets where there is local shortage which could reflect in higher prices.

- To stabilize price of the commodity, Government could establish viable storage facilities couple with introduction of weights and measures at both producing and consuming markets and involve brokers to process and store the commodity for a fee. If this is properly done, the price of commodity would be stabilized and guaranteed for both farmers and the consuming public.

\subsection{Direction for Further Research}

The paper covered only maize which is an important cereal in Ghana. However future studies could investigate price interaction among cereals and legumes.

\section{References}

Abdulai, A., (2000). Spatial Price Transmission and Asymmetry in the Ghanaian Maize Market. Journal of Development Economics, Vol. 63, Issue 2, pp. 327-349.

Adegeye, A. J. and Dittoh, S., (1986). Increasing cocoa production through effective marketing of cocoa spraying chemicals in Nigeria. Agricultural Administration Vol. 22, Issue 2, pp. 105-115.

Alderman, H., (1992). Inter-commodity Price Transmittal. Oxford Bulletin of Economics and Statistics. Vol. 55, Issue 1, pp. 43-64.
Anthonio, Q. B. O., (1973). Problem of marketing agricultural produce with special reference to foodstuffs in Nigeria. In factors of agricultural growth in West Africa (ed). I.M. Ofori 251-262 Institute of Statistical Social and Economic research.

Ardeni, P. G., (1989). Does the law of one price really hold for commodity prices? American Journal of Agricultural Economics. Vol. 71, Issue 3, pp. 661 669.

Armah, P.L., (1989). Post-harvest maize marketing efficiency: the Ghanaian experience. Doctoral Thesis submitted to University College of Wales, Aberystwyth. 353 pp.

Badiane, O. and Shively, G. E., (1998). Spatial Integration, Transportation Costs, and the Response of Local Prices to policy Changes in Ghana. Journal of Development Economics, Vol. 56, pp. 411-431.

Blyn, G., (1973). Price series correlation as a measure of market integration. Indian Journal of Agricultural Economics Vol. 28, Issue 2, pp. 56-59.

Charemza, W.W. and Deadman, D.F., (1993). New Directions in Econometric Practice: General to Specific Modelling, Cointegration and Vector Autoregression. Edward Elgar Publishing Limited, England.

Dittoh, S., (1994). Market integration. The case of dry season vegetables in Nigeria. Department of Agricultural Economics University of Ibadan Nigeria. African Rural Social Sciences Research Networks. Issues in African Rural Development, Steven, A. B, (ed) Winrock International,

Eicher, C. K. and Baker, D. C., (1982). Research on agricultural development in sub-Saharan Africa. A critical Survey. MSU International Development Paper No. 1. Department of Agricultural Economics. East Lansing Michigan State University.

Fackler, P.L. and Tastan, H., (2008). Estimating the Degree of Market Integration. American Journal of Agricultural Economics, Vol. 90, Issue 1, pp. 69-85.

FAO., (2003). Commodity Market Review 2003-2004. Commodities and Trade Division Food and Agriculture Organization of the United Nations Rome.

Ghana Statistical Service., (2000). The Fourth Round of the Ghana Living Standards Survey (GLSS IV). Ghana Statistical Service, Accra

Gilbert, E. H., (1969). The marketing staple food in Northern Nigeria. A case study of the staple food marketing systems servicing Kano city. $\mathrm{PhD}$ thesis, Stanford University.

Granger, C. W. J., (1988). Some recent development in the concept of Causality. Journal of Econometrics Vol. 39, Issue 1-2, pp. 199 - 211.

Harris, B., (1979). There is method in my madness or is it vice versa? Measuring agricultural 
performance. Food Research Institute Studies Vol. 17, Issue 2, pp. $197-218$.

Jensen, R., (2007). The Digital Provide: Information (Technology), Market Performance, and Welfare in the South Indian Fisheries Sector. Quarterly Journal of Economics, Vol. 122, Issue 3, pp. 879-924.

Jones, W. O., (1968). The structure of staple food marketing in Nigeria as revealed by price analysis. Food Research Institute Studies Vol. 8, Issue 2, pp. 95123.

Jones, W. O., (1972).Marketing staple foods in tropical Africa. Journal of Development Economics Vol. 63, Issue 2, pp. 327-349.

Kwadzo, G. T-M. and Srofenyoh, F., (2012).Understanding Institutional Arrangements in the Maize Value Chains in Ghana. In agriculture and social development in Ghana, some pocily issues (ed), Anaman, A.K., Zackaria, A., Okyere, Y.C., Srofenyoh, F., Kwadzo, G. T-M., Yaro A.J., Alhassan, S., and Bawakyillenuo, S., (2012). For Institute of Democratic Governance (IDEG), Accra.

Mabaya, E., (2003). Smallholder agricultural markets in Zimbabwe: Organization, spatial integration and equilibrium. A Doctoral Thesis presented to the Cornell University, Ithaca, N.Y.

Miracle, M. P., (1968). Market structure in commodity trade and capital accumulation in West Africa. In Markets and marketing in development economies (ed), Moyer, R. and Hollande, S., 209-27, Homewood Illinois Irwin.

Nyanteng, V.K. and Asuming-Bempong, S., (2003). The Role of Agriculture in the Food Security of Ghana. Paper presented at the "Roles of Agriculture Project". International Conference, 20-23 October 2003. Available

ftp:/ /ftp.fao.org/es/esa/roa/pdf/4_Food_Securi ty/FoodSecurity_Ghana.pd.

R.Ihle, R. and Amikuzuno, J., (2009). The Integration of Tomato Markets in Ghana with and without Direct Trade Flows. Contributed Paper prepared for presentation at the International Association of Agricultural Economists Conference, Beijing, China, August 16-22, 2009. Available at http://ageconsearch.umn.edu/bitstream/51402/2 /534.pdf

SRID., (2010). Agriculture in Ghana, Facts and Figures. Ministry of Food and Agriculture, Accra, Ghana.
Stephens, E.C., Mabaya, E., von Cramon-Taubadel, S. and Barrett, C. B., (2008). Spatial Price Adjustment with and without Trade. Working paper series. Available

Thodey, A. R., (1969). Analysis of staple food price behaviour in Western Nigeria. PhD Thesis. University of Illinois.

Wayo Seini, A., (2002). Agricultural growth and competitiveness under policy reforms. In Ghana Technical Publication No. 61. Institute of Statistical, Social \& Economic Research (ISSER) University of Ghana, Legon. Available at http://searchworks.stanford.edu/view/5542810

Wilcock, D. C., (1978). The political economy of grain marketing and storage in the Sahel. African Rural Economy. Working Paper No. 24. Department of Agricultural Economics, East Lansasing Michigan State University. 